\title{
External Dependence of the African Franc CFA zone. Empirical Investigations on Money Supply Process
}

\section{Souleymane Ndao*}

Nikolay Nenovsky

\section{Summary}

The objective of this paper is to study the operating mechanisms of the issuing institutions in CFA area and the different sources of money creation. Our approach consists in studying, respectively the automatic or discretionary nature of monetary policies, through the establishment of nonneutralization/non-sterilization monetary indices (index); and in a second step we test, using co-integration models, the evolution of monetary base in relation of Net External Asset (NFA) and in relation to the evolution of Net Domestic Assets. Our results mainly indicate the existence of a preponderance of the external sector or NFA over the evolution of the monetary base or money supply, compared to the domestic sector. In addition, we observe an automatic adjustment in both WAEMU and CEMAC over the long term. But the return to equilibrium is slower in WAEMU due to a mix of automation and discretion. On the other hand, in CEMAC, the return to equilibrium is almost automatic with a strong dependence on the external sector.
Keywords: CFA Zone, African monetary integration, Adjustment mechanisms, Currency Boards, monetary dependence.

JEL: E51, E58, F45, 055

\section{INTRODUCTION}

Comprising 14 countries in West and Central Africa: Benin, Burkina, Cote d'Ivoire, Guinea Bissau, Mali, Niger, Senegal et Togo (WAEMU) and Central African countries: Cameroon, Central African Republic, Congo, Gabon, Equatorial Guinea and Chad (CEMAC), the CFA zone symbolizes a unique example of monetary cooperation with seventy years of experience. It is indeed a real "case of study" both in terms of its longevity and in terms of the nature of its institutional and monetary functioning (Bloch-Laine, 1956).

Policy makers generally view the experience as positive, highlighting the benefits of macroeconomic stability, particularly low inflation, and how it has stimulated institutional development (Cabrillac and Rocher, 2013; Hugon, 1990; Masson and Pattillo, 2004). However, the question of the costs of sustainable exchange rate fixation (monetary dependence) is often ignored in the current debate. Especially since most member countries are sensitive to major shocks, such as the current drop in oil prices per barrel,

\footnotetext{
Bordeaux Management School, Dakar, and CRIISEA, University of Picardie Jules Verne, France

" CRIISEA, University of Picardie Jules Verne, France and Department of Theoretical Economics, SU HSE, Russia
} 


\section{Articles}

the sustainable fixed exchange rate in the CFA zone and the resulting dependence on other types of regimes or monetary arrangements are a particular feature. In this respect, the rigidity of this monetary policy" and the way in which the "comptes d'opérations" (operating accounts) guarantee unlimited convertibility between the anchor currency and the CFA francs justify analyzing the degree of autonomy or dependence in the two monetary unions in the CFA zone (WAEMU and CEMAC). To do this, we will first establish an index of "non-neutralization"
External Dependence of the African Franc CFA zone.

Empirical Investigations on Money Supply Process

(or non-sterilization) of monetary policy, and then, using an econometric model, we compare the functioning of the two regional issuing institutions with other sustainable fixed regimes such as "currency boards".

\section{CURRENCY BOARDS AND CFA ZONE. INSTUTUTIONAL ASPECTS}

Defenders of Currency Boards consider that they offer a stable exchange rate and monetary regime to a developing country with an unstable macroeconomic history ${ }^{2}$.

Table 1. comparison of institutional characteristics between the CFA zone and Currency Boards

\begin{tabular}{|c|c|c|}
\hline & Zone CFA & Currency Board \\
\hline Discipline/status & Compulsory compliance with agreements & Strict compliance with the law \\
\hline Fixed exchange rate & FCFA with a fixed parity & Absolute fixed rate to a main foreign currency \\
\hline Coverage & $100 \%$ of the monetary base & $100 \%$ of the monetary base \\
\hline Convertibility & Unlimited insurance by France treasury & Unlimited convertibility \\
\hline Lender of Last Resort & Residual (France treasury) & $\begin{array}{l}\text { Non-existent } \\
\text { (or limited if excess reserves) }\end{array}$ \\
\hline Credibility & Low inflationary bias & Low inflationary bias \\
\hline costs & $\begin{array}{l}\text { Inability to react to shocks } \\
\text { Dependent monetary policy }\end{array}$ & $\begin{array}{l}\text { Monetisation of the government deficit is } \\
\text { forbidden } \\
\text { Dependent monetary policy }\end{array}$ \\
\hline
\end{tabular}

Source: the authors compilations

The two types of monetary regimes, the CFA zone and the Currency Board, impose external balance constraints to the detriment of domestic economic policy. They are very rigid, since the discretionary actions of monetary authorities are limited but also very restrictive in that they impose limits on monetary creation and public finances, so that they are often considered particularly vulnerable to crises, and are also seen as obstacles to economic growth.
Their monetary liabilities vary according to foreign exchange reserves and balance of payments dynamics. In other words, the change in the money supply can only be made if there is a change in the quantity of foreign exchange reserves in advance. An upward trend in these reserves would lead to an increase in the supply of monetary base; and inversely, if foreign reserves diminish, - monetary base will decline (Hanke and Schuler, 1994).

\footnotetext{
${ }^{1}$ Monetary policy is the process of managing the central bank's money supply in order to achieve specific objectives, such as limiting inflation, maintaining an exchange rate, achieving full employment and economic growth.

2 Thus, currency boards regimes are not only likely to ensure monetary stability, but also prevent the authorities from using any devaluation or inflation to demonetize debt.
} 


\section{Articles}

\section{MONETRAY AUTONOMY OF THE CFA ZONE: EMPIRICAL STUDY}

Our study covers the period 1980-2016, with annual data mainly collected through the balance sheets of the two Central Banks (BCEAO and BEAC) and from the annual reports of the Banque de France. In order to simplify and highlight the two main sources of monetary creation (external and domestic sources), we have previously carried out work to group together the items in the initial balance sheets of the two Central Banks. For example, net domestic assets (NDA) are obtained as the sum of net claims on banks and net claims on Treasuries, the latter as the sum of claims on national Treasuries plus operations on behalf of national treasuries less deposits from Treasuries and other public institutions etc. It should be noted that there are some differences in the items between the balance sheets of the two Central Banks, but careful work is needed to synchronize them. We have obtained the following results.

The accumulation of foreign exchange reserves in Currency Board regimes generally exceeds the $100 \%$ limit of the monetary base. Such additional reserves can be used to help with liquidity problems in the banking sector. This violates the regulations prescribed upstream and can affect the variation of reserves relative to the monetary base. In other words, it disrupts the automatic adjustment. The coverage ratio of demand liabilities, i.e. banknotes issued and bank deposits with the bank by the Central Bank's official assets, is $20 \%$ under the staff regulations. On the eve of the devaluation in 1993, this rate was $17 \%$. In December 1994, the coverage rate exceeded $80 \%$. Since then, the coverage of the monetary issue has crossed the $100 \%$.

Based on the balance sheets of the two banks, and after some modifications (explained later in the data set), we obtained the dynamics of the coverage presented in graph 1: we clearly see the overrun of the legal $20 \%$ threshold, and especially the huge accumulation in CEMAC (unlike WAEMU, coverage in CEMAC is never officially announced, see for example the annual reports of the zone delivered by the Banque de France).

Figure 1. Monetary base coverage (in \%)

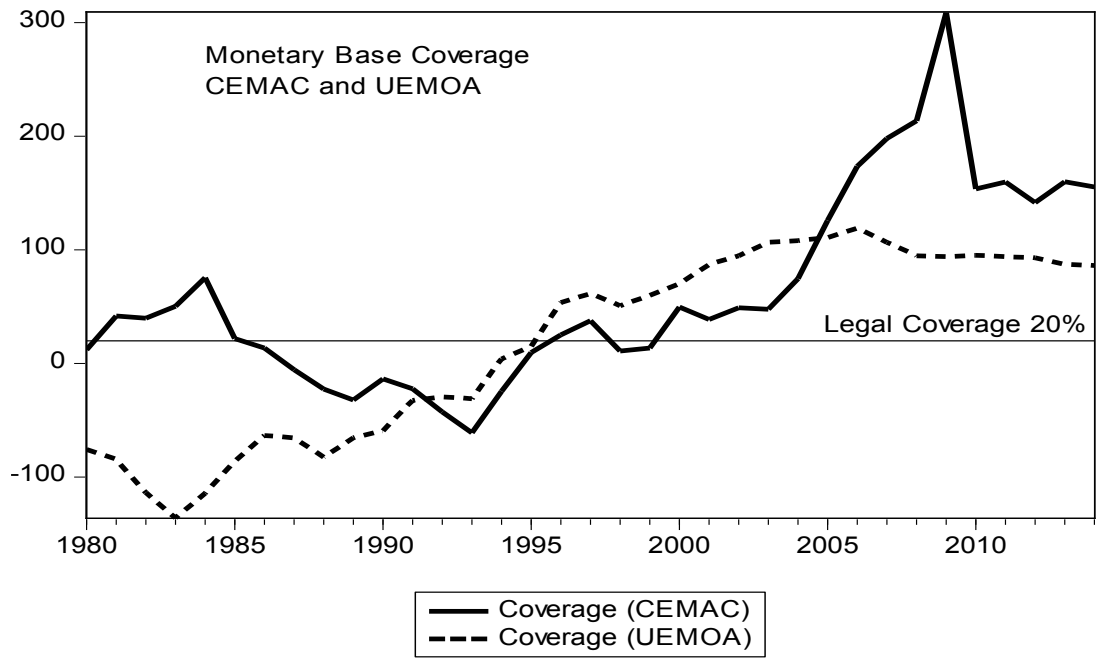

Sources: BCEAO, BEAC, reconstitution of balance sheets and our calculations 


\section{Articles}

External Dependence of the African Franc CFA zone.

Empirical Investigations on Money Supply Process

This hedging dynamic attests to a disconnection between monetary policy and fiscal policy. In addition, the degree of automatic adjustment depends on the degree of coverage of the money supply. This automatic adjustment consists of a set of interactions linking the balance of payments to the money supply, which allows the balance to return to balance following a shock, without the discretionary action of the monetary authority ${ }^{3}$. And a significant currency coverage also implies increased credibility in the currency, because of the assurance of convertibility. Currency coverage is linked to the operation of the "comptes d'opérations" opened by the area's issuing institutions with the French Treasury and a number of requirements. The transaction account presents the degree of freedom, discretion that possess the monetary power in relation to the Currency Board rule.

Figure 2. Evolution of the "comptes d'opérations" in the two unions of the CFA zone (in mIrd CFA)

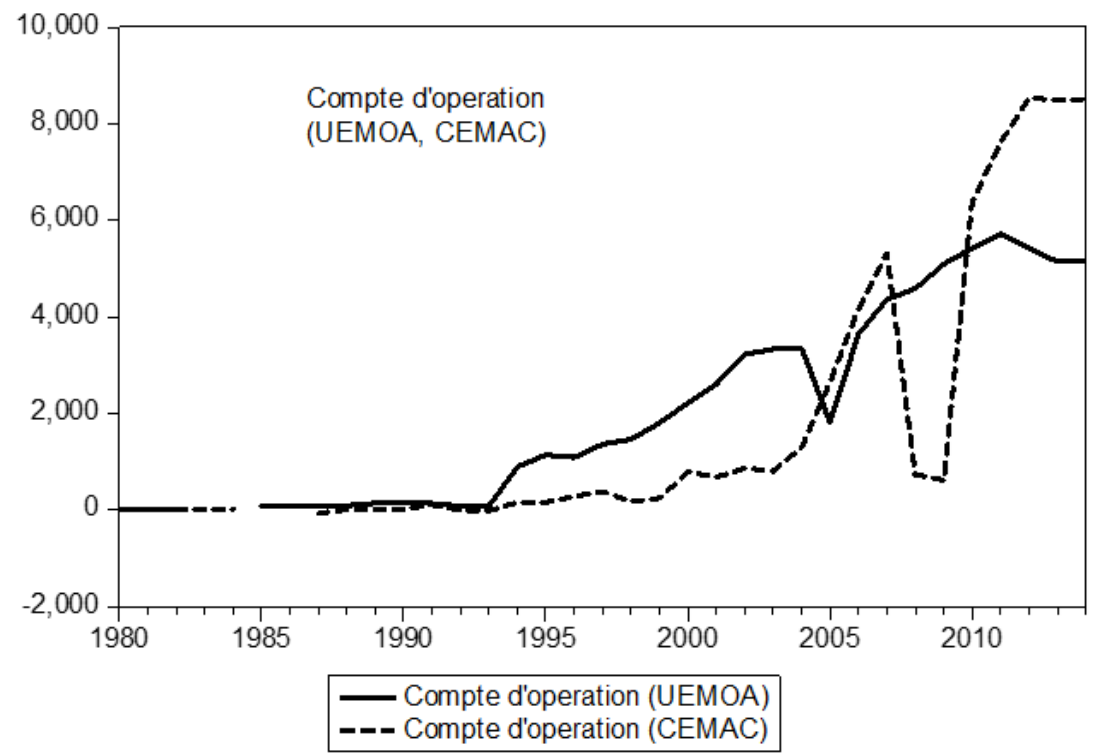

Source: BCEAO, BEAC, reconstitution of balance sheets and our calculations

These figures show that the two Central Banks rarely encountered difficulties (i.e. deficit) with their "comptes d'opérations", except of course during periods of crisis (atypical periods), particularly in the mid1980s and early 1990s, corresponding to the so-called economic crisis of the 1980s, and on the eve of the 1994 devaluation. This scrupulous respect of the operating conditions of the "comptes d'opérations" is only one illustration of the discipline that has prevailed since the devaluation began.

A simple way of checking the extent to which money creation in the CFA zone is close to the principles of "Currency Boards" would be to start from the principle of the "nonsterilization" policy. The "non-sterilization" that must be respected in a currency board regime

\footnotetext{
${ }^{3}$ The automatic adjustment works in its purest version in a pure gold standard regime, because of the direct relationship between the balance of payments and the currency stock that is linked to the gold stock.

${ }^{4}$ Non-sterilization also indicates that the movements of foreign and domestic assets do not move in the opposite direction, and even more restrictively - do not offset each other.
} 


\section{Articles}

means that discretionary monetary policy is non-existent. In other words, monetary base movements are determined only by foreign exchange reserves. Indeed, in the monetary practice of modern central banks, sterilization (or neutralization) consists in breaking the link changes in net domestic assets and the monetary base. In this logic, the sterilization coefficient $k$ (further developed by Hanke, 2002) highlights the ratio of the change in net domestic assets $(D)$ to net foreign assets $(F)$ ( $t$ is a time operator) (see eq.1).

$k=\frac{\Delta D t}{\Delta F t}$
As a result, if complete sterilization is involved, i.e. domestic assets and net foreign assets vary in the opposite direction, the coefficient $k=-1$. On the contrary, if the Currency Board is orthodox, i.e. the complete absence of domestic assets in the Central Bank's assets, the coefficient $k$ is equal to or close to 0 . The neutralization is then partial if $k$ is between 0 and -1 . When $k>-1$, we speak of over-sterilization (excessive sterilization), while when $k>1$, we speak of the two sources of the monetary base moving in the same direction. From the data thus constructed, we obtain the non-sterilization coefficients for WAEMU and CEMAC.

Figure 3. coefficient of non-sterilization in WAEMU

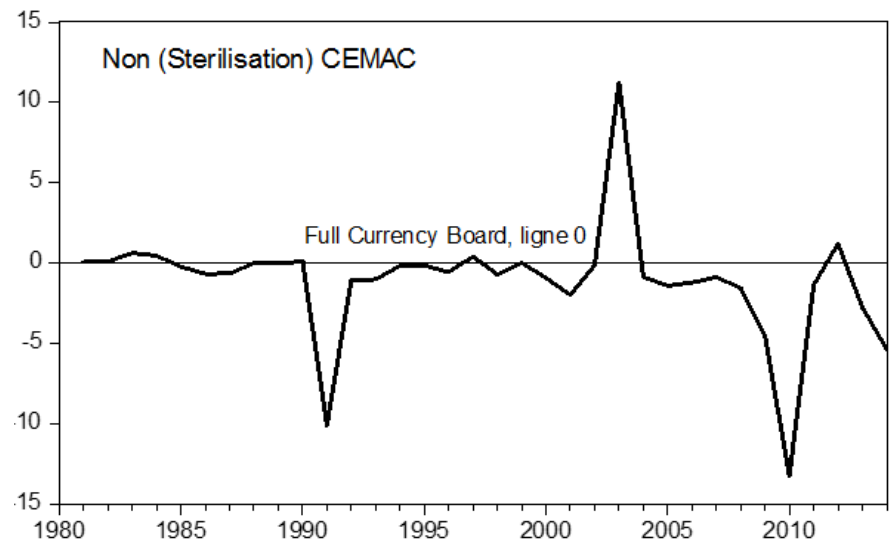

Source: BCEAO, BEAC, reconstitution of balance sheets and our calculations

Figure 4. coefficient of non-sterilization in CEMAC

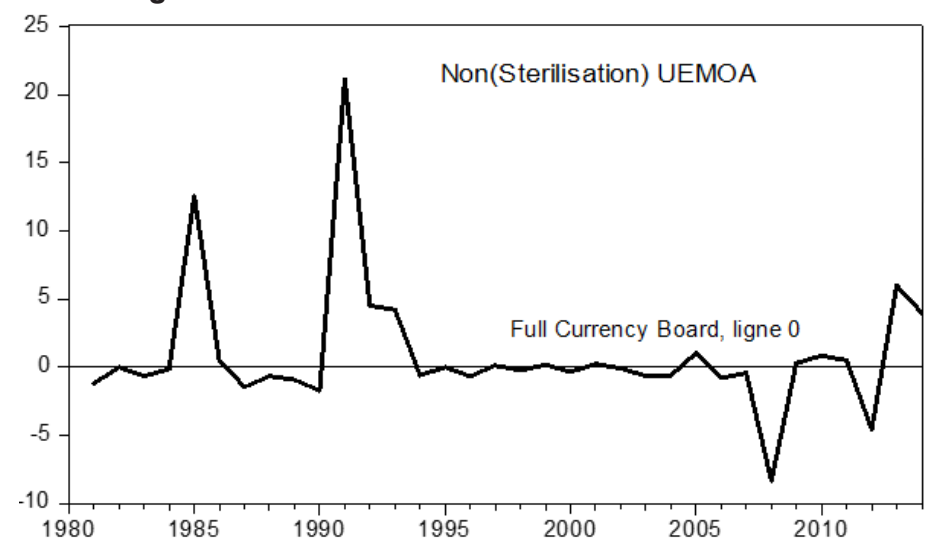

Source: BCEAO, BEAC, reconstitution of balance sheets and our calculations 


\section{Articles}

The two curves show the periods when both banks operated as a pure Currency Boards ( $k$ close to 0$)$. In the period of devaluation, as well as in the recent period (especially after the crisis) the elements of deviation and sterilization have appeared. The negative sign of the coefficients proves that there is an inverse correlation between domestic assets and net foreign assets, and therefore excessive sterilization. In some cases, (CEMAC around 2000, and UEMOA, after 2012, for example) there is a positive correlation $(k>1)$, i.e. monetary authorities reinforce the impulses from the balance of payments by manipulating domestic net assets in the same direction.

\section{ECONOMETRIC INVESTIGATIONS}

Through these econometric tests, we try to evaluate the adjustment mechanism, i.e. the level of dependence of monetary policy. Indeed, the evaluation of the effectiveness of the adjustment makes it possible to establish the type of dependence and rigidity in terms of monetary creation. Thus, the dependence ${ }^{5}$ on monetary creation, following the evolution of the balance of payments, i.e. the unlimited convertibility of the monetary base into reserve currency irrevocably, exerts an undeniable brake on the financing of the budget.

However, the automatic adjustment mechanism is effective when the evolution of the money supply follows the dynamics of the balance of payments or the external sector. In doing so, greater dependence on one of these sources (external and/or domestic), through induced adjustment, would indicate the nature of autonomy or dependence in both unions in the area. By using the same database (1980-2016), we seek to determine
External Dependence of the African Franc CFA zone.

Empirical Investigations on Money Supply Process

whether or not there is a long-term adjustment mechanism between the balance of payments (foreign net assets) and the monetary base (co-integration relationship). At the same time, we are interested in short-term dynamics (VEC) via the Error Correction mechanism. In short-term vector we put variables such as the trading account, the devaluation in 1994, or domestic credit. Thus, the long-term relationship is written:

$h_{t}=\alpha_{0}+\alpha_{1} f_{t}+\varepsilon_{t}$

The short-term adjustment is described as follows:

$$
\begin{aligned}
\Delta h_{t}= & A(L) \Delta h_{t-1}+B(L) \Delta f_{t-1}+ \\
& C(L) \Delta c o_{t-1}+D(L) \Delta l_{t-1}+ \\
& E(L) \Delta i_{t-1}+\delta\left(h_{t-1}-\right. \\
& \left.\alpha 1 f_{t-1}-\alpha_{0}\right)+\beta_{0}+\vartheta_{0}
\end{aligned}
$$

Where, $h$ is the monetary base, $f$ is the net foreign assets, $c o$ the "compte d'opération», $l$ is the domestic credit, and $i$ the key interest rate, all (except the interest rate) expressed in log. $\delta$ is the Error Correction term (tested as a negative sign).

The long-term relationship between the monetary base and foreign exchange reserves, i.e. the external sector, makes it possible to judge the nature of the automatic adjustment. On the other hand, the relationship between the change in the monetary base and the domestic sector must be anecdotal. The adjustment mechanism tends to bring the monetary base back into long-term equilibrium, relative to the external sector. According to Granger's theorem, the co-integrated variables always converge. Therefore, a significant EC term is the indicator of the existence of valid co-integration relationship. After determining the order of integration of the variables,

\footnotetext{
${ }^{5}$ This dependence is reflected in the government's ability to accumulate foreign exchange, particularly in reserve currency, since the increase can only be achieved when there is an increase in the quantities held in the anchor currency. Otherwise, this would not only generate costs; it would also weaken the economy in question, with various implications since the exchange rate instrument for making adjustments can no longer be used given the type of parity.
} 


\section{Articles}

we obtained the results summarized in the following tables. We have presented the different models according to the variables included in the short-term dynamics, while

keeping in mind the long-term relationship between the monetary base and foreign net assets.

Table 2. Cointegration and Error Correction (VEC): WAEMU

\begin{tabular}{|c|c|c|c|c|c|}
\hline & \multicolumn{2}{|c|}{\begin{tabular}{|l} 
UEMOA \\
(WITH INTEREST RATE)
\end{tabular}} & \multicolumn{3}{|c|}{$\begin{array}{l}\text { UEMOA } \\
\text { (WITH devaluation) }\end{array}$} \\
\hline Variables* & \multicolumn{2}{|c|}{$\begin{array}{l}\text { Dependent Variable } \\
\text { Monetary base (h) }\end{array}$} & \multicolumn{3}{|c|}{$\begin{array}{l}\text { Dependent Variable } \\
\text { Monetary base (h) }\end{array}$} \\
\hline Constant & \multirow{2}{*}{\multicolumn{2}{|c|}{$\begin{array}{l}3.24 \\
0.59(5.78)\end{array}$}} & \multirow{2}{*}{\multicolumn{2}{|c|}{$\begin{array}{l}0.36 \\
1.08(6.84)\end{array}$}} & \\
\hline \multirow[t]{3}{*}{ Foreign Reserves (f) } & & & & & \\
\hline & \multicolumn{5}{|c|}{ VEC equations (short-term relations) } \\
\hline & VEC1 (h) & VEC2 (f) & VEC1 (h) & VEC2 (f) & VEC3 (dev) \\
\hline Coefficient of correction & $-0.02(-0.11)$ & $0.74(3.34)$ & $-0.09(-0.10)$ & $0.67(4.48)$ & $-0.09(-0.10)$ \\
\hline$d(h(-1))$ & $-0.38(-1.65)$ & $-0.43(-1.57)$ & $0.00(-0.03)$ & $0.00(-0.02)$ & $0.00(-0.02)$ \\
\hline$d(h(-2))$ & $-0.27(-1.35)$ & $-0.31(-1.29)$ & & & \\
\hline$d(f(-1))$ & $-0.01(-0.04)$ & $-0.15(-0.91)$ & 0.09 (1.11) & $0.02(0.15)$ & $0.09(-1.11)$ \\
\hline$d(f(-2))$ & $-0.21(-1.51)$ & $-0.10(-0.67)$ & & & \\
\hline$d(i)$ & $0.06(0.65)$ & $0.02(0.19)$ & & & \\
\hline Devaluation 1994 & & & $-1.21(-5.82)$ & $-0.80(-2.29)$ & $-1.21(-5.82)$ \\
\hline Constant & $0.03(0.21)$ & $0.12(0.59)$ & $0.10(3.1)$ & $0.09(1.92)$ & $0.10(3.1)$ \\
\hline $\mathrm{R} 2$ & 0.26 & 0.34 & 0.66 & 0.43 & 0.19 \\
\hline $\mathrm{R} 2$ adjusted & 0.09 & 0.18 & 0.62 & 0.35 & 0.07 \\
\hline log likelihood & 3.16 & -3.07 & 16.65 & -0.73 & 14.91 \\
\hline F statistics & 1.49 & 2.16 & 13.88 & 5.37 & 1.67 \\
\hline
\end{tabular}

* $\mathrm{T}$ statistics in parentheses

Table 3. Co-integration and Error Correction (VEC) : CEMAC

\begin{tabular}{|c|c|c|c|c|c|}
\hline & \multicolumn{2}{|c|}{$\begin{array}{l}\text { CEMAC } \\
\text { (WITH COMPTE D'OPÉRATION) }\end{array}$} & \multicolumn{3}{|c|}{$\begin{array}{l}\text { CEMAC } \\
\text { (WITH devaluation) }\end{array}$} \\
\hline Variables* & \multicolumn{2}{|c|}{$\begin{array}{l}\text { Dependent Variable } \\
\text { Monetary base (h) }\end{array}$} & \multicolumn{3}{|c|}{$\begin{array}{l}\text { Dependent Variable } \\
\text { Monetary base (h) }\end{array}$} \\
\hline Constant & \multirow{2}{*}{\multicolumn{2}{|c|}{$\begin{array}{l}41.63 \\
4.73(3.59)\end{array}$}} & \multirow{2}{*}{\multicolumn{2}{|c|}{\begin{tabular}{|l}
12.21 \\
$-0.55(-0.75)$
\end{tabular}}} & \\
\hline \multirow[t]{3}{*}{ Foreign Reserves (f) } & & & & & \\
\hline & \multicolumn{5}{|c|}{ VEC equations (short-term relations) } \\
\hline & VEC1 (h) & VEC2 (f) & VEC1 (h) & VEC2 (f) & VEC3 (dev) \\
\hline Coefficient of correction & $-0.21(-2.90)$ & $0.17(2.48)$ & $-0.43(-3.90)$ & $-0.08(-0.57)$ & $0.02(-0.02)$ \\
\hline $\mathrm{d}(\mathrm{h}(-1))$ & $-0.70(-9.55)$ & $-0.12(-1.61)$ & $-0.48(-4.54)$ & $0.07(0.52)$ & $-0.00(-0.02)$ \\
\hline $\mathrm{d}(\mathrm{h}(-2))$ & $-0.65(-7.87)$ & $-0.07(-1.61)$ & $-0.41(-3.84)$ & $0.06(0.46)$ & $-0.01(-0.21)$ \\
\hline$d(f(-1))$ & $-0.89(-3.15)$ & $-0.04(-0.17)$ & $-0.10(-0.63)$ & $-0.56(-2.66)$ & $-0.00(-0.08)$ \\
\hline$d(f(-2))$ & $-0.72(-3.38)$ & $-0.02(-0.12)$ & $-0.29(-1.86)$ & $-0.29(1.42)$ & $-0.00(-0.02)$ \\
\hline$d(c 0)$ & $0.81(2.89)$ & $0.03(0.14)$ & & & \\
\hline Devaluation 1994 & & & $-0.09(-4.73)$ & $-0.11(-0.25)$ & $-0.04(-0.18)$ \\
\hline
\end{tabular}


External Dependence of the African Franc CFA zone.

Articles

Empirical Investigations on Money Supply Process

\begin{tabular}{|c|c|c|c|c|c|}
\hline & \multicolumn{2}{|c|}{$\begin{array}{l}\text { CEMAC } \\
\text { (WITH COMPTE D'OPÉRATION) }\end{array}$} & \multicolumn{3}{|c|}{$\begin{array}{l}\text { CEMAC } \\
\text { (WITH devaluation) }\end{array}$} \\
\hline Variables* & \multicolumn{2}{|c|}{$\begin{array}{l}\text { Dependent Variable } \\
\text { Monetary base (h) }\end{array}$} & \multicolumn{3}{|c|}{$\begin{array}{l}\text { Dependent Variable } \\
\text { Monetary base (h) }\end{array}$} \\
\hline Constant & \multirow{2}{*}{\multicolumn{2}{|c|}{$\begin{array}{l}41.63 \\
4.73(3.59)\end{array}$}} & \multirow{2}{*}{\multicolumn{2}{|c|}{$\begin{array}{l}12.21 \\
-0.55(-0.75)\end{array}$}} & \\
\hline \multirow[t]{3}{*}{ Foreign Reserves (f) } & & & & & \\
\hline & \multicolumn{5}{|c|}{ VEC equations (short-term relations) } \\
\hline & VEC1 (h) & VEC2 (f) & VEC1 (h) & VEC2 (f) & VEC3 (dev) \\
\hline Constant & $-7.52(-2.84)$ & $-0.33(-0.12)$ & $-12.85(-3.1)$ & $-1.52(-0.43)$ & $1.13(0.58)$ \\
\hline $\mathrm{R} 2$ & 0.92 & 0.43 & 0.94 & 0.29 & 0.02 \\
\hline R2 adjusted & 0.89 & 0.29 & 0.91 & 0.02 & 0.00 \\
\hline log likelihood & -5.43 & -4.92 & -0.68 & -8.26 & 9.35 \\
\hline F statistics & 41.10 & 2.93 & 41.51 & 1.08 & 0.07 \\
\hline
\end{tabular}

${ }^{*} t$ statistics in parentheses

Table 4. Co-integration and Error Correction (VEC): CEMAC

\begin{tabular}{|c|c|c|}
\hline & \multicolumn{2}{|c|}{$\begin{array}{l}\text { CEMAC } \\
\text { (WITH INTEREST RATE) }\end{array}$} \\
\hline Variables* & \multicolumn{2}{|c|}{$\begin{array}{l}\text { Dependent Variable } \\
\text { Monetary base (h) }\end{array}$} \\
\hline Constant & \multirow{2}{*}{\multicolumn{2}{|c|}{$\begin{array}{l}41.63 \\
0.52(1.35)\end{array}$}} \\
\hline \multirow{2}{*}{ Foreign Reserves (f) } & & \\
\hline & VEC1 (h) & VEC2 (f) \\
\hline Coefficient of correction & $-0.95(-7.27)$ & $-0.02(-1.14)$ \\
\hline$d(h(-1))$ & $-0.09(-0.92)$ & $0.01(0.15)$ \\
\hline$d(h(-2))$ & $-0.11(-1.93)$ & $-0.07(-1.61)$ \\
\hline$d(f(-1))$ & $0.12(0.70)$ & $-0.58(-2.92)$ \\
\hline$d(f(-2))$ & $-0.16(-0.97)$ & $-0.30(-1.59)$ \\
\hline$d(i)$ & $-2.16(-8.23)$ & $-0.02(-0.09)$ \\
\hline \multicolumn{3}{|l|}{$d(c o)$} \\
\hline \multicolumn{3}{|l|}{ Devaluation 1994} \\
\hline Constant & $4.10(8.21)$ & $0.69(0.12)$ \\
\hline R2 & 0.92 & 0.28 \\
\hline R2 adjusted & 0.90 & 0.10 \\
\hline log likelihood & -3.54 & -8.04 \\
\hline F statistics & 52.64 & 1.62 \\
\hline
\end{tabular}

${ }^{*} \mathrm{t}$ statistics in parentheses 


\begin{tabular}{|c|c|c|c|c|}
\hline & \multicolumn{2}{|c|}{$\begin{array}{l}\text { WAEMU } \\
\text { (WITH DOMESTIC CREDIT) }\end{array}$} & \multicolumn{2}{|c|}{$\begin{array}{l}\text { CEMAC } \\
\text { (WITH Domestic Credit) }\end{array}$} \\
\hline Variables* & \multicolumn{2}{|c|}{$\begin{array}{l}\text { Dependent Variable } \\
\text { Monetary base (h) }\end{array}$} & \multicolumn{2}{|c|}{$\begin{array}{l}\text { Dependent Variable } \\
\text { Monetary base (h) }\end{array}$} \\
\hline Constant & \multirow{2}{*}{\multicolumn{2}{|c|}{ 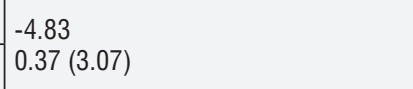 }} & \multirow{2}{*}{\multicolumn{2}{|c|}{$\begin{array}{l}-5.60 \\
0.20(2.22)\end{array}$}} \\
\hline \multirow[t]{3}{*}{ Foreign Reserves (f) } & & & & \\
\hline & \multicolumn{4}{|c|}{ VEC equations (short-term relations) } \\
\hline & VEC1 (h) & VEC2 (f) & VEC1 (h) & VEC2 (f) \\
\hline Coefficient of correction & $-0.10(-0.55)$ & $0.82(3.80)$ & $-0.36(-2.16)$ & $0.10(0.89)$ \\
\hline $\mathrm{d}(\mathrm{h}(-1))$ & $-0.30(-1.42)$ & $-0.41(-1.66)$ & $-0.37(-1.73)$ & $-0.10(-0.73)$ \\
\hline $\mathrm{d}(\mathrm{h}(-2))$ & $-0.23(-1.19)$ & $-0.27(-1.24)$ & $-0.10(-0.57)$ & $-0.14(-1.16)$ \\
\hline$d(f(-1))$ & $-0.00(-0.04)$ & $-0.32(-1.98)$ & $0.35(1.23)$ & $-0.43(-1.83)$ \\
\hline$d(f(-2))$ & $-0.19(-1.37)$ & $-0.25(-1.52)$ & $-0.16(-0.49)$ & $-0.08(-0.32)$ \\
\hline$d(I)$ & $0.02(0.22)$ & $-3.38(-3.06)$ & $0.35(1.90)$ & $-0.10(-0.84)$ \\
\hline Constant & $-0.06(-0.07)$ & $3.30(3.18)$ & $-2.44(-1.76)$ & $0.88(0.93)$ \\
\hline R2 & 0.26 & 0.40 & 0.65 & 0.25 \\
\hline R2 adjusted & 0.12 & 0.26 & 0.51 & 0.12 \\
\hline log likelihood & 3.07 & -1.65 & 3.42 & 13.26 \\
\hline F statistics & 1.46 & 2.75 & 1.58 & 1.11 \\
\hline
\end{tabular}

${ }^{*} t$ statistics in parentheses

\section{CONCLUDING COMENTS}

The different models show important results and highlight some difference in adjustment in the monetary policy of the two central banks. Overall, there is a positive relationship between net foreign assets and the monetary base, which to some extent confirms the dependence on monetary creation from external sources. In the case of CEMAC, this dependence is even more pronounced, because we obtain the vectors in the short term with an adjustment towards long-term values. The parameter in front of the "comptes d'opérations", for example, is significant and helps to restore the balance between external assets and the long-term monetary base. The introduction of domestic credit in the short-term dynamics also exposes a difference between WAEMU and CEMAC.

For WAEMU there is a vector where credit increases the monetary base, while in
CEMAC, the direction of the relationship is the opposite, credit decreases the monetary base. This could mean a much more restrictive policy for CEMAC than for WAEMU, and this goes hand in hand with the results obtained for the coverage ratio and the dynamics of sterilization. In the end, the monetary creation in WAEMU is dependent on the balance of payments, and the econometrical results show that the CEMAC is even more dependent.

We observe that in these types of monetary regimes with a sustainable and quasi-irrevocable fixity, monetary policy tends to be more dependent on foreign exchange reserves, as in the case of Currency Boards. This would imply that the money base or supply would depend more on the change in the stock of reserves at the expense of the domestic sector. Thus, in the face of external shocks, a minimum of discretion on the part of the authority would make it possible 


\section{Articles}

to reduce costs, since the weakness of the labour market and the industrial fabric will not make it possible to offset the effect of these shocks on the real economy.

However, in the two currency unions in the CFA zone, in the short term, there are no automatic rebalancing. In other words, short-term adjustment is not sufficient to restore the equilibrium (especially in the context of WAEMU). In general, this difficulty of automatic adjustment is inherent in the functioning of a Currency Board because of the primacy given to the objective of macroeconomic stabilization to the detriment of other development objectives. Thus, fiscal policies appear less consistent with the monetary policy of the area and therefore more restrictive. The autonomy of monetary policy in the area has not been stable.

First, following a structural change in 1994, monetary policy shifted towards less autonomy. Second, central banks also target a specific level of reserves, so that the ability of money supply to respond to foreign exchange reserves would change with the level of reserves. Other instruments designed to limit the deficit in the "comptes d'opérations" do not seem to have a significant influence on monetary policy. The rule that currency boards use for monetary policy is consistent with their exchange rate commitment. This is also true in the CFA zone.

In this article we have demonstrated, through the analysis of the operating model of the issuing institutions in the zone, the coverage thresholds for monetary issuance, the level of sterilization of the currency and the nature of the adjustment mechanism, in the light of the Currency Board regimes, that the monetary policy of two issuing institutions is largely dependent. This dependence appears to be stronger for CEMAC, with a faster adjustment mechanism compared to that of
External Dependence of the African Franc CFA zone.

Empirical Investigations on Money Supply Process

WAEMU - where this adjustment is delayed from time to time by various constraints related to the organization of the arrangement in the long term.

The comparative analysis of the adjustment mechanisms of the monetary regime in the CFA zone with other similar forms such as Currency Boards, which maintain their exchange rate stability on a sustainable basis, indicates a form of natural dependence on monetary policy. This dependence would be all the more visible in the present of negative shocks of a certain magnitude, which would affect the viability of the unions. Moreover, setting the exchange rate in a sustainable way makes monetary policy binding. The restrictive nature of fixed or sustainable anchorage regimes and the fragility of flexibility regimes make the task more complicated for developing economies such as those in the CFA area. That is why we consider the middle ground solution as a credible and stable alternative. This would avoid excessive holding of foreign exchange reserves that generate costs for member countries.

Final note. The ideas for this empirical test were formed in the period 2015-2017, within the framework of the doctorate of Souleymane Ndao and as a result of the experience that Nikolay Nenovsky had within the framework of the Currency Board of Bulgaria. The tests unequivocally reaffirmed the need to reform the CFA zone. Today, when we publish these tests, three years later, the facts are there. In early 2020, it was decided that the franc area should be restructured. The details of this reform (some of which have not yet been clarified) generally confirm our forecasts and models. In this sense, in addition to a purely historical (cliometric) value, our study sheds light on theories of common monetary zones. 
Articles

\section{References}

BCEAO, 2000. Histoire de l'Union monétaire ouest-africaine, 3 vol., Paris, ed. Georges Israël.

Bloch-Lainé, F., ed. 1956. La Zone Franc, Paris, PUF.

Desquilbet, J., and Nenovsky, N., 2005. Confiance et ajustement dans les régimes d'étalon-or et de caisse d'émission", Mondes en développement, 130 (2), pp.77-93.

Cabrillac, B. and Rocher E., 2013. Les perspectives des unions monétaires africaines, Revue d'économie financière, 2 (110), pp. 99-124.

Cohen, B., 1998. The Geography of Money, Ithaca, Cornel University Press.

Cooper, F., 2012 (2002). L'Afrique depuis 1940, Paris, Payot.

Fosu, A., 2012. Institutions and African Economies: An Overview, Journal of African Economies, 22(4), pp.491-498.

Hanke, S., 2002. On Dollarization and Currency Boards: Error and Deception, Policy Reform, 5 (4), pp.203-222.

Hanke, S. and Schuler K., 1994. Currency Boards for Developing Countries, International Center for Economic Growth, San Francisco, ICS Press.

Hanke, S., 2002. On dollarization and Currency Boards: Error and Deception, Working Paper on Policy Reform, Policy Reform, 5(4), pp. 203-222.
Hugon, P., 1990. Zone monétaire et intégration régionale: le cas de la zone franc", Techniques Financières et Développement, Epargne Sans Frontières, No 21.

Krus, N., 2012. The Money Supply in Currency Boards, Studies in Applied Economics, No3.

Lelart, M., 1996. L'origine du compte d'opérations, La France et l'outremer: Un siècle de relations monétaires et financières, Comité pour l'histoire économique et monétaire de la France, 529 (45).

Masson, P. and Pattillo C., 2004. The Monetary Geography of Africa: Washington: The Brookings Institution.

Ndao, S., Nenovsky, N. and Tochkov K., 2019 Does monetary integration lead to income convergence in Africa? a study of the CFA monetary area, Portuguese Economic Journal 18, pp. 67-85. Avaiable: https://doi. org/10.1007/s10258-018-0150-8

Nenovsky, N., Hristov, K. and Mihaylov M., 2001. Comparing Currency Board Automatic Mechanism in Bulgaria, Estonia and Lithuania, Journal des Economistes et des Etudes Humaines, 11(4).

Nenovsky, N. and Hristov, K., 2002. New Currency Boards and discretion. The empirical evidence from Bulgaria, Economic Systems, March, 26(1), pp. 55-72.

Shortland, A. and Stasavage, D., 2004. What Determines the Monetary Policy in the Franc Zone? Estimating a Reaction Function for the BCEAO, Journal of African Economies, 13 (4), pp. 518-35. 